\title{
Leukemia stem cells: the root of chronic myeloid leukemia
}

\author{
Hong Zhou ${ }^{1,2}$, Rongzhen $\mathrm{Xu}^{1,2 \bowtie}$ \\ ${ }^{1}$ Key Laboratory of Cancer Prevention and Intervention, China National Ministry of Education, Department of Hematology, \\ Zhejiang University, Hangzhou 310009, China \\ ${ }^{2}$ Cancer Institute, Second Affiliated Hospital, School of Medicine, Zhejiang University, Hangzhou 310009, China \\ $\square$ Correspondence: zrxyk10@zju.edu.cn (R. Xu) \\ Received December 19, 2014 Accepted February 10, 2015
}

\begin{abstract}
Chronic myeloid leukemia (CML) is a clonal myeloproliferative disorder characterized by a chromosome translocation that generates the Bcr-Abl oncogene encoding a constitutive kinase activity. Despite remarkable success in controlling CML at chronic phase by Bcr-Abl tyrosine kinase inhibitors (TKIs), a significant proportion of CML patients treated with TKIs develop drug resistance due to the inability of TKIs to kill leukemia stem cells (LSCs) that are responsible for initiation, drug resistance, and relapse of CML. Therefore, there is an urgent need for more potent and safer therapies against leukemia stem cells for curing CML. A number of LSCassociated targets and corresponding signaling pathways, including CaMKII- $y$, a critical molecular switch for co-activating multiple LSC-associated signaling pathways, have been identified over the past decades and various small inhibitors targeting LSC are also under development. Increasing evidence shows that leukemia stem cells are the root of CML and targeting LSC may offer a curable treatment option for CML patients. This review summarizes the molecular biology of LSC and itsassociated targets, and the potential clinical application in chronic myeloid leukemia.
\end{abstract}

KEYWORDS chronic myeloid leukemia (CML), leukemia stem cells (LSCs), tyrosine kinase inhibitors (TKIs),

CaMKII-y, molecular switch

\section{INTRODUCTION}

It is well established that cancers depend on a small population of "cancer stem cells" (CSCs) for maintaining their uncontrolled growth. Early insight into the molecular pathogenesis of cancer stemmed from the discovery of activating oncogenes, such as Bcr-Abl oncogene and its constitutively active protein tyrosine kinase, in CML (NOWELL and HUNGERFORD, 1960; Rowley, 1973; Druker, 2008). The Bcr-Abl oncogenic tyrosine kinase is responsible for initiating and maintaining the leukemia phenotype of $\mathrm{CML}$ cells. This oncoprotein is also responsible for the phosphorylation, activation and dysregulation of intracellular signaling proteins that regulate the survival and growth of progenitor cells in the bone marrow (Tauchi et al., 1994; Kabarowski and Witte, 2000). Although tyrosine kinase inhibitors (TKIs) for Bcr-Abl oncoprotein revolutionized the treatment of $\mathrm{CML}$ at chronic phase (CML-CP), $25 \%$ of TKI-naive patients and $50 \%-90 \%$ of patients with TKI-resistance contain leukemic clones expressing TKI-resistant Bcr-Abl kinase mutants (Slupianek et al., 2013). Studies have shown that a number of factors, including activation of critical signal transduction pathways, cell cycle alterations, abnormal epigenetic events and aberrant microenvironment from the hematopoietic niche, contribute to the enhanced survival and continued growth of CML stem/progenitor cells. This review will focus on the molecular biology of LSC and its-associated targets, and the potential clinical application in chronic myeloid leukemia.

\section{LEUKEMIA STEM CELLS OF CHRONIC MYELOID LEUKEMIA}

Stem cells are defined as functional rather than morphological or any other physical feature. The current definition of stem cell remains the same as it established by McCulloch and Till, which are characterized by three distinct properties: self-renewal, differentiation capability, and proliferative capacity (Molofsky et al., 2005). These properties make stem cells to produce and maintain a diverse and specialized 
group of cells. In addition to maintaining their undifferentiated state by self-renewal, stem cells also generate progenitors that differentiate to form cells of multiple lineages upon successive divisions.

CML has long been considered as a stem cell disease, but detailed characteristics of its stem cells have not been fully elucidated to date. Because CML has the propensity to evolve from a chronic phase to accelerated phase and finally to blast crisis phase, one can pinpoint the phase and developmental stage at which mutations arise. Hence, CML is an important paradigm for understanding both genetic and epigenetic events that drive aberrant stem and progenitor cell differentiation, self-renewal and survival during both early and advanced phases of disease (Lowe and Sherr, 2003). In vitro studies using long-term culture-initiating cell (LTC-IC) assays showed the presence of pluripotent stem cells of malignant origin in patients with CML (Chen et al., 1994). The majority of CML progenitors were found to have a higher proliferative capacity compared to normal progenitors, suggesting that most CML progenitors were actively cycling (Eaves et al., 1998).

The concept that cancer/leukemia stem cells (CSCs/ LSCs) are responsible for initiation, drug resistance, and relapse of cancers has inflamed this area of research and the importance of CSCs has been demonstrated in a variety of tumors (Morrison et al., 1995; Weissman, 2000; Al-Hajj et al., 2003). In CML and other malignancies, studies have shown that LSCs are able to self-renew, which leads to therapeutic resistance and disease progression (Olsson et al., 2014).

A model for leukemogenesis shows that the malignant transformation of normal hematopoietic stem/precursor cells would give rise to LSCs (Dash et al., 2002; Zhao et al., 2004; Strathdee et al., 2007), which retains the key characteristics of self-renewal and proliferative capacity but do not differentiate to mature cells. Because current therapies for leukemia are designed based on the general biological properties of malignant blast cells with proliferation potential, whereas LSCs are frequently in a quiescent state. Thus, current strategies do not effectively eliminate the LSCs as well as the disease (Holyoake et al., 1999).

\section{Quiescence of leukemia stem cells}

Although the precise molecular mechanism of LSC-mediated resistance to current therapies has not been fully elucidated, one critical factor might be the quiescence of LSC that allows this population cells to evade the targeting by current therapies. In CML, abnormal tyrosine kinase-directed phosphorylation and mislocalization of cell cycle proteins have been implicated in deregulation of the cell cycle in Bcr-Abl expressing cells, which means that CML quiescent LSCs are TKI resistant and represent a Bcr-Abl kinase-independent disease reservoir (Cramer et al., 2008). Leukemia stem cells, particularly those in a quiescent state, are highly resistant to current chemotherapies and targeted therapies, resulting in disease relapse (Ito et al., 2008; Kaminska et al., 2008). In addition, signaling molecules involved in cell survival and self-renewal, which are the two critical characteristics of quiescent LSC, have been linked to key regulators of the cell cycle.

Studies have revealed that LSCs residing in the bone marrow niche are dormant and resistant to traditional chemotherapies. Specific signals from the surrounding stromal cells might promote LSCs cell cycle arrest and allow them to persist even during treatment with TKI therapies. Imatinib mesylate (IM), the first drug designed to target the Bcr-Abl kinase, induces hematologic and cytogenetic remissions in the majority of CML patients at chronic phase, however, the $\mathrm{Bcr}-\mathrm{Abl}$ kinase domain mutations portend a greater risk of loss of complete cytogenetic remission (CCR) (Molofsky et al., 2005). Ultimately, regardless of greatly reduced mortality rates with Bcr-Abl targeted therapy, a significant proportion of patients are expected to develop TKI resistance driven by quiescent LSCs, which may be a reservoir for disease progression to blast crisis. Several studies demonstrate that a quiescent population of $\mathrm{CML}$ stem cells $\left(\mathrm{CD} 34^{+} \mathrm{CD} 38^{-} \mathrm{CD}^{-} 5 \mathrm{RA}^{-} \mathrm{CD} 71^{-} \mathrm{HLA}^{-} \mathrm{DR}^{\text {low }}\right.$ ) with Bcr-Abl kinase domain mutations, detectable prior to initiation of imatinib therapy, gives rise to leukemia cells that persist because they are inherently resistant to imatinib (Sorel et al., 2004; Molofsky et al., 2005; Barnes and Melo, 2006; Jiang et al., 2007; Jorgensen et al., 2007; Niemann et al., 2007; Wodarz, 2008; Olsson et al., 2014). This may be attributable in part to quiescent LSCs residing in the protective niches that acquire additional mutations over time. In addition, quiescent $\mathrm{CD} 34^{+}$progenitors at chronic phase increases the expression levels of chemokines associated with stem cell mobilization (Dierks et al., 2008). Also, several oncogenic transcription factors that regulate cell-fate decision in HSCs and have been implicated in myeloid leukemia, such as MEIS1 and HOXA9, were found to be overexpressed in blast-crisis CML (Jamieson et al., 2004a, b). HOXA9 overexpression leads to the transformation of primary bone marrow cells through specific collaboration with MEIS1 (Kroon E et al., 1998). It has been suggested that HOXA9 forms ternary complexes with PBX2 and MEIS1 in myeloid leukemic cells (Shen WF et al., 1999). These results indicate that the ternary complex, including HOXA9, plays an important role in inducing leukemia, Cooperative activation of MEIS1 and HOXA9 perturbs myeloid differentiation and eventually leads myeloid progenitors to leukemia.

\section{Self-renewal and survival of leukemia stem cells}

Deregulation of programmed cell death or apoptosis allows cancer stem cells to propagate even as they detach from the niche and accumulate genetic mutations. In CML, resistance to apoptosis begins with Bcr-Abl, and notably, the final consequence of Bcr-Abl inhibition with imatinib is induction of apoptosis (Holyoake et al., 1999). CML stem cell resistance to apoptosis involves the aberrant expression of the 
Bcl-2 family of apoptosis-regulatory proteins, including antiapoptotic members, such as Bcl-2 and Mcl-1, and proapoptotic members, such as Bad and Bim (Bedi et al., 1994; Cramer et al., 2008). In addition, activation of the $\mathrm{Wnt} / \beta$ catenin pathway leads to increased c-myc expression and ultimately results in upregulation of $\mathrm{Bcl}-2$ family proteins. However, Neviani et al. reported that protein phosphatase 2A (PP2A)-activating drugs (PADs) can markedly reduce the survival and self-renewal of CML quiescent HSCs, but not normal quiescent HSCs through Bcr-Abl kinase-independent and PP2A-mediated inhibition of JAK2 and $\beta$-catenin (Neviani et al., 2013). In addition, autocrine TNF-alpha production supports the survival of CML stem and progenitor cell and enhances their proliferation (Gallipoli et al., 2013).

Several important apoptosis proteins are also highly regulated by the PI3K/Akt pathway (Cramer et al., 2008). Akt directly inhibits Bad and Bax and modulates the activity of transcription factors such as those from the NF-KB and FoxO families (Ito et al., 2008; Kaminska et al., 2008). NF-kB protein activation leads to its nuclear localization, where it then activates the transcription of a number of pro-survival molecules including $\mathrm{Bcl}-2, \mathrm{Bcl}-\mathrm{xl}$, and various caspase inhibitors (Cramer et al., 2008). The importance of these transcription factors in $C M L$ has been highlighted by the fact that NF-KB is activated in transgenic models of CML and that Bcr-Abl can activate NF-kB (Kaminska et al., 2008). FoxO transcription factors, on the other hand, are targeted for proteolysis via Akt-mediated signaling (Khorashad et al., 2008). These factors normally induce the transcription of prodeath molecules including Bim and FasL. In CML, Bcr-Abl causes constitutive repression of FoxO3a by continued activation of Akt, leading to another mechanism of Bcr-Ablmediated apoptotic resistance (Khorashad et al., 2008; Scheller et al., 2013). Finally, Akt can inhibit GSK3 $\beta$ activity. Thus, the Akt pathway is involved in apoptosis regulation via regulation of GSK3 $\beta$ in CML. Although many survival pathways are upregulated in $\mathrm{CML}$, they are also active in normal stem cells. Thus, revealing the differential expression profiles of survival-related genes between normal hematopoietic stem cells and leukemia stem cells will be critical for designing therapies that selectively eradicate $\mathrm{CML}$ stem cells while sparing normal stem cells.

\section{Aberrant differentiation of leukemia stem cells}

In CML progenitors at blast crisis, the characteristic block of myeloid differentiation is resulted from Bcr-Abl and MAPK (ERK1/2)-induced hnRNP-E2 RNA-binding protein-mediated suppression of C/EBPa expression (Chang et al., 2007). The imatinib and nilotinib resistance, which is derived in part from autocrine granulocyte-macrophage colony-stimulating factor (GM-CSF) secretion in response to adaptive JAK2/STAT5 signaling in granulocyte-macrophage progenitors (GMPs), may be overcome by JAK2 inhibitor (Wang et al., 2007; Gallipoli et al., 2014). In addition to cell autocrine effects, study results from a tetracycline-off mouse model revealed that osteopontin, an essential component of the stem cell niche, was upregulated in Bcr-Abl positive cells (Jamieson et al., 2004a, b). Similarly, osteopontin levels were higher in the serum of patients with CML and contributed to maintain the malignant clones at extramedullary sites (Jamieson et al., 2004a, b). A genetically defined mouse model of blast crisis CML demonstrated that coincident overexpression of genes that skew differentiation, such as Bcr-Abl and NUP98/ HoxA, also resulted in the production of an imatinib-resistant LSC population (Dash et al., 2002; Neering et al., 2007). Together these data suggest that the block of differentiation and the enhancement of self-renewal in CML stem cells may be a critical step of disease progression.

\section{SIGNALING PATHWAYS OF LEUKEMIA STEM CELLS}

Self-renewal is an essential property of stem cells, but the aberrant activation of self-renewal related signaling pathways has been recognized as a hallmark of cancer (Lowe and Sherr, 2003; Jamieson et al., 2004a, b). Wnt genes encode small secreted proteins existing in all animal genomes, and Wnt signaling is involved in virtually every aspect of embryonic development and also controls homeostatic self-renewal in a number of adult tissues. Studies have shown that the developmental pathways, such as the Wnt signaling pathway and the polycomb-group protein Bmi1, are involved in the regulation and expansion of LSCs during CML blast crisis (Chen et al., 1994; Reya et al., 2001; Saudy et al., 2014). The Wnt pathway, which is critical for HSC selfrenewal and interaction with bone marrow niche, was found to be activated during progression to advanced phase in CML patients at blast crisis (Lowe and Sherr, 2003). Selfrenewal capacity is normally absent in GMP, but some studies reveal that inappropriate activation of the Wnt pathway in GMPs endows these cells with self-renewal capacity, as measured by generation of replatable myeloid colonies (Lowe and Sherr,2003), suggesting that these GMPs acquires a key property of a leukemia stem cell. $\beta$-Catenin is also essential for survival of LCSs. In some cases $\beta$-catenin activation is associated with deregulation of GSK3 $\beta$, an essential negative regulator of $\beta$-catenin, in both stem and progenitor cells, while other patients exhibit defective expression of another negative regulator of the pathway-axin 2 (Liu et al., 2005; Quaiser et al., 2006). The progression to myeloid blast crisis can be averted in a $\beta$-catenin knockout mouse model of CML (Sengupta and Banerjee, 2007).

Aberrant activation of another self-renewal program, Sonic hedgehog, was shown to induce expansion of LSCs in a mouse model of $\mathrm{CML}$, while another study reported that there might be a cross-talk between sonic hedgehog, Wnt, and notch pathways in CML (Williams et al., 2008; Hu et al., 2009). The Hedgehog ( $\mathrm{Hh}$ ) signaling pathway is a developmental pathway that has been shown to play a role in primitive and adult hematopoiesis (Morrison et al., 1995). The 
Hh pathway activity is required for maintaining the normal and leukemia stem cells, and raising the possibility that the drug resistance and disease recurrence might be avoided by targeting the essential stem cell maintenance pathway. Strathdee et al. reported that the $\mathrm{Hh}$ signaling was activated in LSCs and differentiated hematopoietic cells through the upregulation of Smo, an essential component of the $\mathrm{Hh}$ pathway (Strathdee et al., 2007). Constitutively activation of Smo increased CML stem cell number and accelerated disease (Zhao et al., 2009), while the loss of Smo impaired HSC renewal (Strathdee et al., 2007).

CaMKII comprises a family of closely related kinases with four isoforms ( $\alpha, \beta, \gamma$, and $\delta$ ). Among these four isoforms, CaMKII- $\gamma$ has been shown to be the major one overexpressed in myeloid cells and its potential role as a regulation of leukemia (Si et al., 2007), inhibition of CaMKII activity correlated with enhanced apoptosis (Hojabrpour et al., 2012). Also, CaMKII-y regulates many fundamental cellular functions and has been implicated in the pathogenesis of several diseases (Si et al., 2007; Si and Collins, 2008). Our study found that both total and phosphor CaMKII-y proteins were highly expressed in the $\mathrm{CD}_{3} 4^{+} / \mathrm{CD} 38^{-} \mathrm{CML}$ LSCs, but low in CD34- CML cells, CD34 ${ }^{+}$HSCs from healthy cord bloods and normal blood cells, suggesting that CaMKII-Y might play a critical role in the survival and proliferation of CML LSCs. CaMKII- $\gamma$ is a specific and critical target of berbamine for its anti-leukemia activity and berbamine selectively binds to CaMKII-y by targeting ATP binding pocket (Gu et al., 2012). Most importantly, CaMKIl-y is a critical molecular switch of multiple cancer-related signaling pathways (Fig. 1), such as NF-kB (Hughes et al., 2001; Gu et al., 2012), Wnt/ $\beta$-catenin (Si and Collins, 2008; Gu et al., 2012), ERK1/2, FoxO1, AKT, and Stat3 signaling pathways (Hughes et al., 2001; Marganski et al., 2005; Ang et al., 2007; Si et al., 2007; Liu et al., 2008; Bouallegue et al., 2009; Timmins et al., 2009; Gu et al., 2012).

Recently, Gerber et al. identified 97 genes that were differentially expressed in CML versus normal stem and progenitor cells by performing genome-wide transcriptome analysis of highly refined $\mathrm{CML}$ and normal stem and progenitor cell populations using exon microarrays. Further analyses of the LSCs revealed dysregulation of normal cellular processes; downregulation of pro-differentiation and TGF-beta/BMP signaling pathways; upregulation of oxidative metabolism and DNA repair pathways; and activation of inflammatory cytokines (Gerber et al., 2013). These data greatly contribute to understanding the molecular changes of LSCs and developing novel therapies for eradicating LSCs and even achieving curable effect of CML.

\section{LEUKEMIA STEM CELL-RELATED TRANSCRIPTION FACTORS}

Progression of CML is associated with transcription factorinduced aberrant lineage priming of stem and progenitor cells. The role of transcription factor deregulation in the differentiation of CML stem cells was demonstrated in a transgenic mouse model with deficiency of a transcription factor, Jun B. Jun B deficiency led to the development of a CML-like disease with a propensity for myeloid differentiation in which serial transplantation potential existed only at the level of HSC (Passegue et al., 2001; Chu et al., 2005). Moreover, GM-CSF-mediated survival and proliferation of Jun B-deficient GMP was associated with anti-apoptotic proteins $\mathrm{Bcl}-2$ and $\mathrm{Bcl}-\mathrm{x}$, and cell cycle regulators $\mathrm{p} 16^{\text {ink4a }}$ and C-Jun (Chu et al., 2005). The transcriptional repressor Bmi1, which is normally restricted to the stem-cell compartment, was found to be overexpressed in the aggressive forms of CML that progress to blast crisis within 3 years and during advanced phases of this disease (Chang et al., 2007).

The E-twenty six (ets) transcription factor GA binding protein (GABP) is a tetrameric transcription factor complex that contains GABPa and GABP $\beta$ proteins. Deletion of GABPa induced cell cycle arrest and profound loss of hematopoietic progenitor cells in bone marrow (Yang et al., 2013). Recently, Yang et al. identified the serine-threonine kinase protein kinase D2 (PRKD2) as a potential effector of GABP in HSCs through bioinformatic screen. PRKD2 can rescue the growth of GABPa-null Bcr-Abl-expressing cells whereas inhibiting PRKD2 expression decreased cell cycling (Yang et al., 2013). These data indicate that GABP is essential for the cell cycle entry of HSC and CML development and may offer a potential therapeutic target for CML.

GATA-2, an important myeloid transcription factor, has been proven to be upregulated in $\mathrm{CML} \mathrm{CD} 34^{+}$cells, whereas stem cell fate determination by the large family of Hox genes is negatively regulated by Bmi1 (Cao et al., 2005; Mohty et al., 2007). Transcription factors HoxA9 and HoxB4 are better known for their transforming potential via enhancing HSC self-renewal and abnormal myelopoiesis upon upregulation (Cao et al., 2005; Strathdee et al., 2007). Downregulation of Hox genes, such as HoxA5, impairs myelopoiesis, suggesting differentiation block at the level of hematopoietic stem cells. Interestingly, hypermethylationmediated inactivation of HoxA4 and HoxA5 was found in $34 \%$ of $\mathrm{CD}_{3} 4^{+}$cells from patients with chronic phase $\mathrm{CML}$ whereas it was observed in up to $90 \%$ of patients with CD34 ${ }^{+}$ CML in blast crisis (Strathdee et al., 2007). Moreover, this hypermethylation-mediated inactivation of HoxA4 and HoxA5 was associated with a poor prognosis in other myeloid and lymphoid malignancies and might be a biomarker of more severe disease (Strathdee et al., 2007).

\section{EPIGENETIC EVENTS IN LEUKEMIA STEM CELLS}

Epigenetic alterations include DNA methylation, histone modifications, and miRNA in the permanent changes of gene expression, which controls the leukemia phenotype. Among these, DNA methylation and histone modification play an important role in leukemogenesis (Esteller, 2008; Jones et al., 2002). For instance, aberrant DNA methylation could 


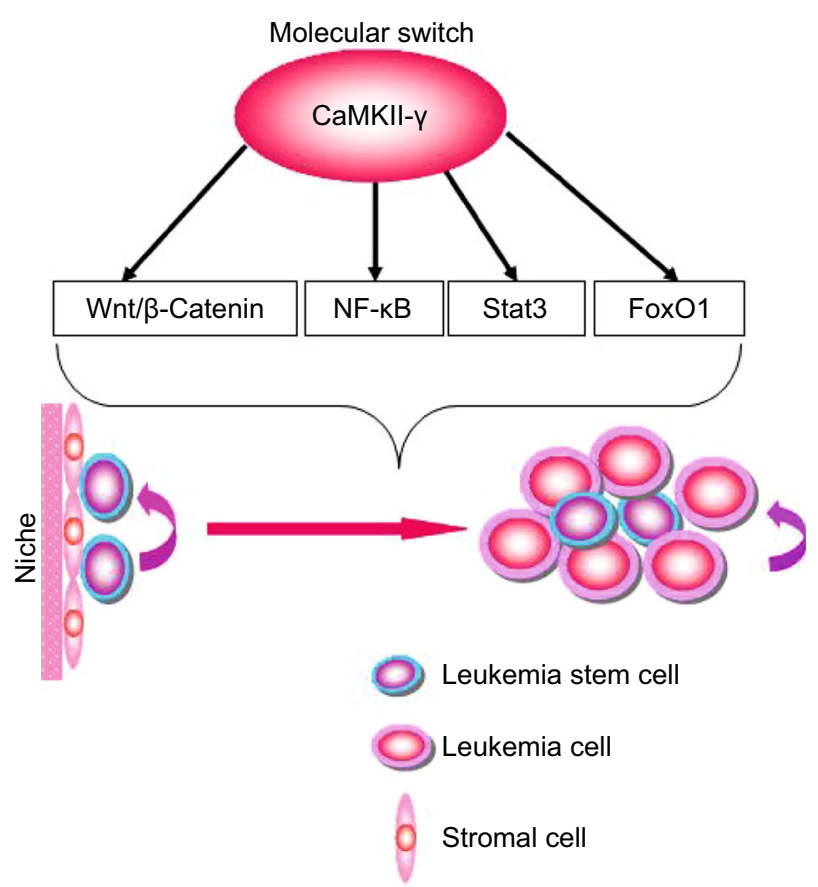

Figure 1. CaMKII-y promotes self-renewal of leukemia stem cells via co-activating multiple signaling pathways.

silence the expression of tumor suppressor genes in leukemia whereas overexpression of the histone methyltransferase, $E Z H 2$, a subunit of the polycomb group repressive complex 2 (PRC2) promotes oncogenesis (Momparler et al., 2012).

SIRT1 deacetylase is a multifunctional protein and can potentially regulate the acetylation of several transcription factors, including p53 (Luo et al., 2001), Ku70, and FoxOs (Brooks and $\mathrm{Gu}, 2009$ ). Recent studies demonstrate that SIRT1 deacetylase not only promotes acquisition of genetic mutations for drug resistance in CML cells but also play a critical role in maintaining the survival of CML LSCs (Wang et al., 2013; Li et al., 2012). SIRT1 activation promotes resistance of CML stem cells to tyrosine kinase inhibitors and acquisition of BCR-ABL mutations for acquired resistance. Consistently, SIRT1 was expressed at higher levels in human CML CD34 ${ }^{+}$cells than in normal CD $34^{+}$cells. Moreover, inhibition of SIRT1 increased apoptosis in LSC of chronic phase and blast crisis CML and reduced their growth in vitro and in vivo. The inhibitory effects of SIRT1 targeting on CML cells depend on p53 expression and acetylation. Importantly, SIRT1 inhibition had less of an effect on proliferation and apoptosis of normal $\mathrm{CD} 34^{+}$cells, suggesting that SIRT1 might be a new target for eliminating CML cancer stem cells. In addition, SIRT1 inhibition in combination with BCR-ABL tyrosine kinase inhibitors might be a novel approach to eliminate leukemic stem cells and residual disease in $\mathrm{CML}$.

Alternative pre-mRNA splicing (AS) is an epigenetic process that greatly diversifies the repertoire of the transcriptome
(Adamia et al., 2013). "Splicing programs" typically react to individual changes with considerable effects in cell proliferation, cell survival, and apoptosis, although the changes in these individual splicing events are small. Evaluation of AS events in $C M L$ can be used to identify new disease markers and sensitive targets in order to overcome the current limits of small molecule inhibitors for the treatment of patients with $\mathrm{CML}$.

\section{CHEMOKINES AND MICROENVIRONMENT OF LEUKEMIA STEM CELLS}

Chemokine is a large protein family that can be divided into subfamilies on the basis of structural motifs. An important property of chemokines is its leukocyte chemotaxis. Chemokines regulate their biological effects via interactions with a family of 7-transmembrane $\mathrm{G}$ protein-coupled receptors. Chemokines, such as stromal-derived factor-1 (SDF-1/ CXCL12) secreted by stromal cells, attracts cancer cells by acting its cognate receptor CXCR4 (Peng et al., 2012). Previous studies indicated that chemokines, which were expressed on hematopoietic and nonhematopoietic tumor cells, were reported to mediate chemotaxis of $\mathrm{CD}_{3} 4^{+}$stem cells, and to play a critical role in the homing and retention of these cells in the microenvironment of bone marrow (Bleul et al., 1996; Kortesidis et al., 2005). In addition, SDF-1 was found to function as both a chemoattractant and as a modulator of cellular growth/survival (Naiyer et al., 1999; Cashman et al., 2002; Liu et al., 2011)

It is unclear why under certain conditions this may promote uncontrolled proliferation, while in other cases cell quiescence may be favored. However, it is possible that the cues from the microenvironment might be involved. The studies support important, new concepts regarding the contribution of leukemia-induced alterations in the BM microenvironment to a selective growth advantage to leukemic compared with normal long-term hematopoietic stem cell (LTHSC) and have relevance to our understanding of the response and resistance to TKI at the organismal level (Zhang et al., 2012). Also, evidence provides new insight into the potential contribution of the microenvironment to the initiation and progression of myeloid disorders and leukemia, and may provide a unique area for the development of combination therapeutic strategies aimed at eradicating the resistant LSC population in CML (Hobbs et al., 1998; Liotta and Kohn, 2001). Signals from the microenvironment have a profound influence on the maintenance and/or progression of hematopoietic cancers.

\section{TARGETING OF LEUKEMIA STEM CELLS}

Despite the curable effect for CML by allogeneic hematopoietic cell transplantation, high transplant-related morbidity and mortality has greatly reduced its use since the development of molecularly targeted therapy (Karanes et al., 2008). Currently, there are three kinds of therapeutic drugs for CML: traditional chemotherapy agents, TKIs, and LSC 
inhibitors, and their working models are shown in Fig. 2. Before the development of Bcr-Abl-targeted therapy, treatment of CML patients at chronic phase is focused primarily on achieving hematologic control, and cytogenetic remission is rare. Moreover, most patients will progress to blast crisis within a few years. Currently, TKIs, which are potent inhibitors of Bcr-Abl protein kinases, c-Kit and the plateletderived growth factor receptor (Valk-Lingbeek et al., 2004; Slupianek et al., 2013), are widely used for treatment of CML due to their highly efficient control of CML at chronic phase. However, These TKIs are unable to kill CML stem cells (Graham et al., 2002). A large number of studies have demonstrated that these TKIs can readily kill most CML cells but only display cytostatic effect on the primitive CML LSCs (Holtz et al., 2002). Consistent with these data, CD34 ${ }^{+}$stem cells from CML patients with complete cytogenetic responses were found to be of malignant origin with the capacity to give rise to CML-BC (Bhatia et al., 2003). These findings indicate that a reservoir of CML LSCs is still maintained in patients who do not show evidence of disease.

The leukemia stem cells in patients with CML are well known to be resistant to conventional chemotherapy and may also be relatively resistant to Bcr-Abl-targeted drugs. Studies have demonstrated the persistence of quiescent CML stem cells that are impervious to Bcr-Abl inhibitor therapy and contribute to disease progression (Holyoake et al., 1999; Chu et al., 2005; Barnes and Melo, 2006; Copland et al., 2006; Jorgensen et al., 2007). The precise sequence of molecular events leading to recalcitrance to Bcr-Abl inhibitor therapy as well as the cellular framework in which they occur has not been elucidated completely. As the properties of leukemia stem cells become better defined, it is possible to evaluate current therapeutic strategies correctly. Identification of therapeutic targets, which are involved in the survival of CML LSCs such as bcl-2; the selfrenewal such as sonic $\mathrm{Hh}$, bmi-1, notch, and Wnt; and the block differentiation such as JAK2/STAT5 activation and HOX gene hypermethylation, will contribute to target LSCs effectively using combinations of small molecule inhibitors and demethylating agents. (Guzman et al., 2005; Neviani et al., 2005; Guzman et al., 2007; Mohty et al., 2008; Bhattacharyya et al., 2009).

Several bcl-2 family member inhibitors are currently under development, JAK2/STAT5 inhibitors are currently being tested in clinical trials and self-renewal pathway inhibitors such as gamma-secretase inhibitors have been used clinically. Several Wnt and sonic hedge-hog inhibitors, which are being evaluated in preclinical models, show promise clinically for eradicating committed progenitors that have aberrantly gained self-renewal capacity. In addition, implementation of strategies to augment both innate and adaptive immune responses against CML progenitors may accelerate disease eradication (Rezvani et al., 2007; Yong et al., 2008).

The eukaryotic translation initiation factor $4 \mathrm{E}$ (elF4E) is a potent oncogene elevated in an estimated $30 \%$ of human cancers (Culjkovic et al., 2009; Siddiqui et al., 2012), and the eIF4E protein provides the critical interface between mRNA, recruitment of elF4A and elF4G, and the $40 \mathrm{~S}$ ribosomal subunits. The activity of elF4F is generally regulated by altering the phosphorylation state of the elF4E component. Increased phosphorylation of elF4E correlates with enhanced translation in cells stimulated with mitogens, growth factors, or serum (Kaspar et al., 1990; Marino et al., 1989). Recently, studies showed that over-phosphoeylation of eukaryotic translation initiation factor 4E (elF4E) led to increased $\beta$-catenin protein synthesis, whereas MAP kinase interacting serine/threonine kinase (MNK) kinase-dependent eIF4E phosphorylation at serine 209 is required for nuclear translocation and activation of $\beta$-catenin. These findings suggest that inhibiting phosphorylation of elF4E may be therapeutically useful in CML-BC (Lim et al., 2013).

RAD51 ( $\operatorname{Rec} A$ homolog of $E$. coli) is a polymorphic gene and one of the central proteins in homologous recombinationDNA-double-stand breaks (HR-DNA-DSB) repair pathway, which is vital in maintaining genetic stability within a cell (Hamdy et al., 2011). RAD51 recombinase activity plays a

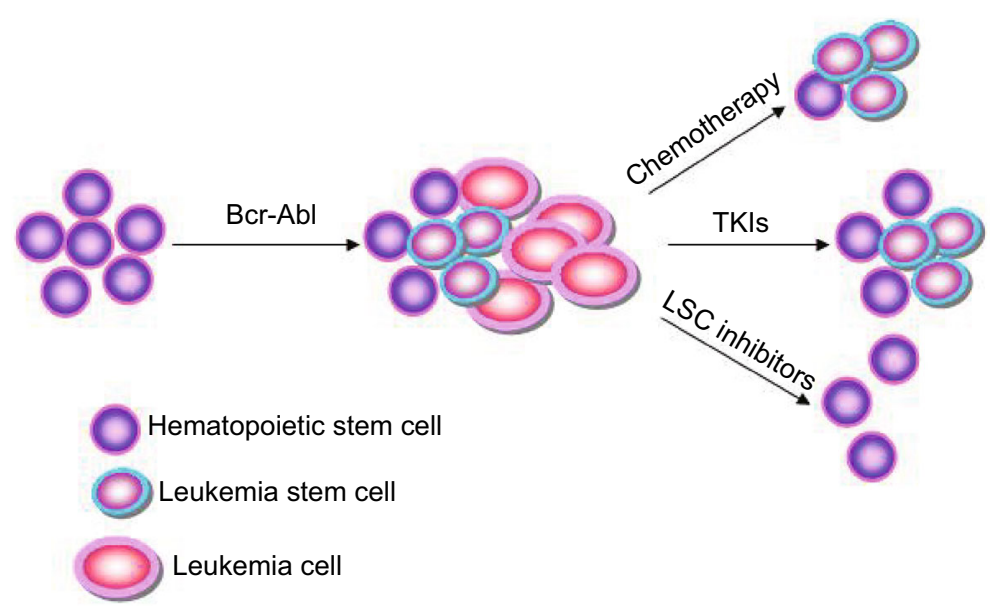

Figure 2. Model of different therapies for chronic myeloid leukemia. Hemotherapy kills both leukemia cells and normal hematopoietic stem cells. TKIs selectively kill leukemia cells but not leukemia stem cells. LSC inhibitors selectively kill leukemia stem cells. 
critical role for cancer cell proliferation and survival, and often contributes to drug-resistance, therefore been proposed as an alternative and supplementary strategy for cancer treatment. IBR2, a novel small molecule that inhibits cancer cell growth and induces apoptosis by inducing proteasome-mediated RAD51 protein degradation, significantly prolonged animal survival in a murine imatinib-resistant $C M L$ model bearing the T315I Bcr-Abl mutation. Moreover, IBR2 effectively inhibits the proliferation of $\mathrm{CD} 34^{+}$progenitor cells from CML patients, suggesting that small molecule inhibitors of RAD51 may provide a novel class of broad-spectrum therapeutics for difficultto-treat cancers (Zhu et al., 2013).

A better understanding of the molecular biology of leukemia stem cells will lead to designing more effective therapies for CML. The challenge includes identification of differences between leukemia stem cells and their normal stem cell counterparts, and demonstration of complete control of leukemia by targeting these cancer stem cells. Recent advances in these areas have identified several novel target candidates that represent important avenues for future therapeutic approaches aimed at selectively eradicating the LSC population while sparing normal hematopoietic progenitors in patients suffering from chronic myeloid leukemia.

\section{ACKNOWLEDGMENTS}

We apologize to the scientists who made contributions to the field, but have not been cited due to the space limitations. This work was supported in part by the National Natural Science Foundation of China (Grant Nos. 81270601, 81328016, and 81470306) and Leukemia Research Innovative Team of Zhejiang Province (2011R50015).

\section{ABBREVIATIONS}

CCR, complete cytogenetic remission; CML, chronic myeloid leukemia; CML-CP, CML at chronic phase; CSC, cancer stem cell; elF4E, eukaryotic translation initiation factor 4E; GABP, GA binding protein; GM-CSF, granulocyte-macrophage colony-stimulating factor; GMP, granulocyte-macrophage progenitor; Hh, Hedgehog; HR-DNA-DSB, homologous recombination-DNA-double-stand breaks; IM, imatinib mesylate; LSC, leukemia stem cells; LTC-IC, long-term culture-initiating cell; LTHSC, long-term hematopoietic stem cell; MNK, MAP kinase interacting serine/threonine kinase; PAD, PP2A-activating drug; PP2A, protein phosphatase 2A; PRC, polycomb group repressive complex; SDF-1, stromal-derived factor-1; TKI, tyrosine kinase inhibitors.

\section{COMPLIANCE WITH ETHICS GUIDELINES}

Rongzhen $\mathrm{Xu}$ and Hong Zhou declare that they have no conflict of interest. This article does not contain any studies with human or animal subjects performed by the any of the authors.

\section{OPEN ACCESS}

This article is distributed under the terms of the Creative Commons Attribution License which permits any use, distribution, and reproduction in any medium, provided the original author(s) and the source are credited.

\section{REFERENCES}

Adamia S, Pilarski PM, Bar-Natan M, Stone RM, Griffin JD (2013) Alternative splicing in chronic myeloid leukemia (CML): a novel therapeutic target. Curr Cancer Drug Targets 13:735-748

Al-Hajj M, Wicha MS, Benito-Hernandez A, Morrison SJ, Clarke MF (2003) Prospective identification of tumorigenic breast cancer cells. Proc Natl Acad Sci U S A 100:3983-3988

Ang ES, Zhang P, Steer JH, Tan JW, Yip K, Zheng MH, Joyce DA, $\mathrm{Xu} \mathrm{J}$ (2007) Calcium/calmodulin-dependent kinase activity is required for efficient induction of osteoclast differentiation and bone resorption by receptor activator of nuclear factor kappa $B$ ligand (RANKL). J Cell Physiol 212:787-795

Barnes DJ, Melo JV (2006) Primitive, quiescent and difficult to kill: the role of non-proliferating stem cells in chronic myeloid leukemia. Cell cycle (Georgetown, Tex.) 5:2862-2866

Bedi A, Zehnbauer BA, Barber JP, Sharkis SJ, Jones RJ (1994) Inhibition of apoptosis by BCR-ABL in chronic myeloid leukemia. Blood 83:2038-2044

Bhatia R, Holtz M, Niu N, Gray R, Snyder DS, Sawyers CL, Arber DA, Slovak ML, Forman SJ (2003) Persistence of malignant hematopoietic progenitors in chronic myelogenous leukemia patients in complete cytogenetic remission following imatinib mesylate treatment. Blood 101:4701-4707

Bhattacharyya J, Mihara K, Yasunaga S, Tanaka H, Hoshi M, Takihara Y, Kimura A (2009) BMl-1 expression is enhanced through transcriptional and posttranscriptional regulation during the progression of chronic myeloid leukemia. Ann Hematol 88:333-340

Bleul CC, Fuhlbrigge RC, Casasnovas JM, Aiuti A, Springer TA (1996) A highly efficacious lymphocyte chemoattractant, stromal cell-derived factor 1 (SDF-1). J Exp Med 184:1101-1109

Bouallegue A, Pandey NR, Srivastava AK (2009) CaMKII knockdown attenuates $\mathrm{H} 2 \mathrm{O} 2$-induced phosphorylation of ERK1/2, PKB/Akt, and IGF-1R in vascular smooth muscle cells. Free Radical Biol Med 47:858-866

Brooks CL, Gu W (2009) How does SIRT1 affect metabolism, senscence and cancer? Nat Rev Cancer 9:123-128

Cao R, Tsukada Y, Zhang Y (2005) Role of Bmi-1 and Ring1A in H2A ubiquitylation and Hox gene silencing. Mol Cell 20:845-854

Cashman J, Clark-Lewis I, Eaves A, Eaves C (2002) Stromal-derived factor 1 inhibits the cycling of very primitive human hematopoietic cells in vitro and in NOD/SCID mice. Blood 99:792-799

Chang JS, Santhanam R, Trotta R, Neviani P, Eiring AM, Briercheck E, Ronchetti M, Roy DC, Calabretta B, Caligiuri MA, Perrotti D (2007) High levels of the BCR/ABL oncoprotein are required for the MAPK-hnRNP-E2 dependent suppression of C/EBPalphadriven myeloid differentiation. Blood 110:994-1003

Chen XS, Sheller JR, Johnson EN, Funk CD (1994) Role of leukotrienes revealed by targeted disruption of the 5-lipoxygenase gene. Nature 372:179-182

Chu S, Xu H, Shah NP, Snyder DS, Forman SJ, Sawyers CL, Bhatia $R$ (2005) Detection of BCR-ABL kinase mutations in CD34 + cells from chronic myelogenous leukemia patients in complete cytogenetic remission on imatinib mesylate treatment. Blood 105:2093-2098 
Copland M, Hamilton A, Elrick LJ, Baird JW, Allan EK, Jordanides N, Barow M, Mountford JC, Holyoake TL (2006) Dasatinib (BMS354825) targets an earlier progenitor population than imatinib in primary CML but does not eliminate the quiescent fraction. Blood 107:4532-4539

Cramer K, Nieborowska-Skorska M, Koptyra M, Slupianek A, Penserga ET, Eaves CJ, Aulitzky W, Skorski T (2008) BCR/ $A B L$ and other kinases from chronic myeloproliferative disorders stimulate single-strand annealing, an unfaithful DNA doublestrand break repair. Cancer Res 68:6884-6888

Culjkovic B, Borden KL (2009) Understanding and targeting the eukaryotic translation initiation factor elF4E in head and neck cancer. J Oncol 2009:981679

Dash AB, Williams IR, Kutok JL, Tomasson MH, Anastasiadou E, Lindahl K, Li S, Van Etten RA, Borrow J, Housman D, Druker B, Gilliland DG (2002) A murine model of CML blast crisis induced by cooperation between BCR/ABL and NUP98/HOXA9. Proc Natl Acad Sci U S A 99:7622-7627

Dierks C, Beigi R, Guo GR, Zirlik K, Stegert MR, Manley P, Trussell C, Schmitt-Graeff A, Landwerlin K, Veelken H, Warmuth M (2008) Expansion of Bcr-Abl-positive leukemic stem cells is dependent on Hedgehog pathway activation. Cancer Cell 14:238-249

Druker BJ (2008) Translation of the Philadelphia chromosome into therapy for CML. Blood 112:4808-4817

Eaves C, Cashman J, Eaves A (1998) Defective regulation of leukemic hematopoiesis in chronic myeloid leukemia. Leuk Res 22:1085-1096

Esteller M (2008) Epigenetics in cancer. N Engl J Med 358:11481159

Gallipoli P, Pellicano F, Morrison H, Laidlaw K, Allan EK, Bhatia R, Copland M, Jorgensen HG, Holyoake TL (2013) Autocrine TNFalpha production supports $\mathrm{CML}$ stem and progenitor cell survival and enhances their proliferation. Blood 122:3335-3339

Gallipoli P, Cook A, Rhodes S, Hopcroft L, Wheadon H, Whetton AD, Jorgensen HG, Bhatia R, Holyoake TL (2014) JAK2/STAT5 inhibition by nilotinib with ruxolitinib contributes to the elimination of CML CD34 + cells in vitro and in vivo. Blood 124:1492-1501

Gerber JM, Gucwa JL, Esopi D, Gurel M, Haffner MC, Vala M, Nelson WG, Jones RJ, Yegnasubramanian S (2013) Genomewide comparison of the transcriptomes of highly enriched normal and chronic myeloid leukemia stem and progenitor cell populations. Oncotarget 4:715-728

Graham SM, Jorgensen HG, Allan E, Pearson C, Alcorn MJ, Richmond L, Holyoake TL (2002) Primitive, quiescent, Philadelphia-positive stem cells from patients with chronic myeloid leukemia are insensitive to STI571 in vitro. Blood 99:319-325

Gu Y, Chen T, Meng Z, Gan Y, Xu X, Lou G, Li H, Gan X, Zhou H, Tang J, Xu G, Huang L, Zhang $X$, Fang $Y$, Wang $K$, Zheng S, Huang W, Xu R (2012) CaMKII gamma, a critical regulator of CML stem/progenitor cells, is a target of the natural product berbamine. Blood 120:4829-4839

Guzman ML, Rossi RM, Karnischky L, Li X, Peterson DR, Howard DS, Jordan CT (2005) The sesquiterpene lactone parthenolide induces apoptosis of human acute myelogenous leukemia stem and progenitor cells. Blood 105:4163-4169

Guzman ML, Li X, Corbett CA, Rossi RM, Bushnell T, Liesveld JL, Hebert J, Young F, Jordan CT (2007) Rapid and selective death of leukemia stem and progenitor cells induced by the compound 4-benzyl, 2-methyl, 1,2,4-thiadiazolidine, 3,5 dione (TDZD-8). Blood 110:4436-4444

Hamdy MS, El-Haddad AM, Bahaa ENM, Makhlouf MM, AbdelHamid SM (2011) RAD51 and XRCC3 gene polymorphisms and the risk of developing acute myeloid leukemia. J Investig Med 59:1124-1130

Hobbs SK, Monsky WL, Yuan F, Roberts WG, Griffith L, Torchilin VP, Jain RK (1998) Regulation of transport pathways in tumor vessels: role of tumor type and microenvironment. Proc Natl Acad Sci U S A 95:4607-4612

Hojabrpour P, Waissbluth I, Ghaffari M, Cox ME, Duronio V (2012) CaMKII-gamma mediates phosphorylation of BAD at Ser170 to regulate cytokine-dependent survival and proliferation. Biochem 442:139-149

Holtz MS, Slovak ML, Zhang F, Sawyers CL, Forman SJ, Bhatia R (2002) Imatinib mesylate (STI571) inhibits growth of primitive malignant progenitors in chronic myelogenous leukemia through reversal of abnormally increased proliferation. Blood 99:37923800

Holyoake T, Jiang X, Eaves C, Eaves A (1999) Isolation of a highly quiescent subpopulation of primitive leukemic cells in chronic myeloid leukemia. Blood 94:2056-2064

Hu Y, Chen Y, Douglas L, Li S (2009) beta-Catenin is essential for survival of leukemic stem cells insensitive to kinase inhibition in mice with BCR-ABL-induced chronic myeloid leukemia. Leukemia 23:109-116

Hughes K, Edin S, Antonsson A, Grundstrom T (2001) Calmodulindependent kinase II mediates $T$ cell receptor/CD3- and phorbol ester-induced activation of IkappaB kinase. J Biol Chem 276:36008-36013

Ito K, Bernardi R, Morotti A, Matsuoka S, Saglio G, Ikeda Y, Rosenblatt J, Avigan DE, Teruya-Feldstein J, Pandolfi PP (2008) PML targeting eradicates quiescent leukaemia-initiating cells. Nature 453:1072-1078

Jamieson CH, Ailles LE, Dylla SJ, Muijtjens M, Jones C, Zehnder JL, Gotlib J, Li K, Manz MG, Keating A, Sawyers CL, Weissman IL (2004a) Granulocyte-macrophage progenitors as candidate leukemic stem cells in blast-crisis CML. N Engl J Med 351:657-667

Jamieson CH, Weissman IL, Passegue E (2004b) Chronic versus acute myelogenous leukemia: a question of self-renewal. Cancer Cell 6:531-533

Jiang X, Saw KM, Eaves A, Eaves C (2007) Instability of BCR-ABL gene in primary and cultured chronic myeloid leukemia stem cells. J Natl Cancer Inst 99:680-693

Jones PA, Baylin S (2002) The fundamental role of epigenetic events in cancer. Nat Rev Genet 3:415-428

Jorgensen HG, Allan EK, Jordanides NE, Mountford JC, Holyoake TL (2007) Nilotinib exerts equipotent antiproliferative effects to imatinib and does not induce apoptosis in CD34 + CML cells. Blood 109:4016-4019

Kabarowski JH, Witte ON (2000) Consequences of BCR-ABL expression within the hematopoietic stem cell in chronic myeloid leukemia. Stem Cells 18:399-408

Kaminska J, Klimczak-Jajor E, Bany-Laszewicz U (2008) Src kinases in the process of maturation megakryocyte progenitors. Postepy Biochem 54:378-383 
Karanes C, Nelson GO, Chitphakdithai P, Agura E, Ballen KK, Bolan CD, Porter DL, Uberti JP, King RJ, Confer DL (2008) Twenty years of unrelated donor hematopoietic cell transplantation for adult recipients facilitated by the National Marrow Donor Program. Biol Blood Marrow Transplant 14:8-15

Kaspar R, Rychlik W, White MW, Rhoads RE, Morris DR (1990) Simultaneous cytoplasmic redistribution of ribosomal protein L32 mRNA and phosphorylation of eukaryotic initiation factor 4E after mitogenic stimulation of Swiss 3T3 cells. J Biol Chem 265:36193622

Khorashad JS, de Lavallade H, Apperley JF, Milojkovic D, Reid AG, Bua M, Szydlo R, Olavarria E, Kaeda J, Goldman JM, Marin D (2008) Finding of kinase domain mutations in patients with chronic phase chronic myeloid leukemia responding to imatinib may identify those at high risk of disease progression. J Clin Oncol 26:4806-4813

Kortesidis A, Zannettino A, Isenmann S, Shi S, Lapidot T, Gronthos $S$ (2005) Stromal-derived factor-1 promotes the growth, survival, and development of human bone marrow stromal stem cells. Blood 105:3793-3801

Kroon E, Krosl J, Thorsteinsdottir U, Baban S, Buchberg A-M, Sauvageau G (1998) Hoxa9 transforms primary bone marrow cells through specific collaboration with Meis1a but not Pbx1b. EMBO 17:3714-3725

Li L, Wang L, Li L, Wang Z, Ho Y, McDonald T et al (2012) Activation of p53 by SIRT1 inhibition enhances elimination of CML leukemia stem cells in combination with imatinib. Cancer Cell 21:266-281

Lim S, Saw TY, Zhang M, Janes MR, Nacro K, Hill J, Lim AQ, Chang CT, Fruman DA, Rizzieri DA et al (2013) Targeting of the MNKelF4E axis in blast crisis chronic myeloid leukemia inhibits leukemia stem cell function. Proc Natl Acad Sci U S A. 110: E2298-E2307

Liotta LA, Kohn EC (2001) The microenvironment of the tumour-host interface. Nature 411:375-379

Liu X, Rubin JS, Kimmel AR (2005) Rapid, Wnt-induced changes in GSK3beta associations that regulate beta-catenin stabilization are mediated by Galpha proteins. Curr Biol 15:1989-1997

Liu X, Yao M, Li N, Wang C, Zheng Y, Cao X (2008) CaMKII promotes TLR-triggered proinflammatory cytokine and type I interferon production by directly binding and activating TAK1 and IRF3 in macrophages. Blood 112:4961-4970

Liu X, Duan B, Cheng Z, Jia X, Mao L, Fu H, Che Y, Ou L, Liu L, Kong D (2011) SDF-1/CXCR4 axis modulates bone marrow mesenchymal stem cell apoptosis, migration and cytokine secretion. Protein Cell 2:845-854

Lowe SW, Sherr CJ (2003) Tumor suppression by Ink4a-Arf: progress and puzzles. Curr Opin Genet Dev 13:77-83

Luo J, Nikolaev AY, Imai S, Chen D, Su F, Shiloh A, Guarente L, Gu W et al (2001) Negative control of p53 by Sir2 alpha promotes cell survival under stress. Cell 107:137-148

Marganski WA, Gangopadhyay SS, Je HD, Gallant C, Morgan KG (2005) Targeting of a novel $\mathrm{Ca}+2$ /calmodulin-dependent protein kinase II is essential for extracellular signal-regulated kinasemediated signaling in differentiated smooth muscle cells. Circ Res 97:541-549

Marino MW, Pfeffer LM, Guidon PT, Donner DB (1989) Tumornecrosis factor induces phosphorylation of a $28 \mathrm{kd}$ mRNA cap-binding protein in human cervical carcinoma cells. Proc Natl Acad Sci U S A 86:8417-8421

Mohty M, Yong AS, Szydlo RM, Apperley JF, Melo JV (2007) The polycomb group BMl1 gene is a molecular marker for predicting prognosis of chronic myeloid leukemia. Blood 110:380-383

Mohty M, Szydlo RM, Yong AS, Apperley JF, Goldman JM, Melo JV (2008) Association between BMl-1 expression, acute graftversus-host disease, and outcome following allogeneic stem cell transplantation from HLA-identical siblings in chronic myeloid leukemia. Blood 112:2163-2166

Molofsky AV, He S, Bydon M, Morrison SJ, Pardal R (2005) Bmi-1 promotes neural stem cell self-renewal and neural development but not mouse growth and survival by repressing the p16Ink4a and p19Arf senescence pathways. Genes Dev 19:1432-1437

Momparler RL, Idaghdour Y, Marquez VE, Momparler LF (2012) Synergistic antileukemic action of a combination of inhibitors of DNA methylation and histone methylation. Leuk Res 36:10491054

Morrison SJ, Uchida N, Weissman IL (1995) The biology of hematopoietic stem cells. Annu Rev Cell Dev Biol 11:35-71

Naiyer AJ, Jo DY, Ahn J, Mohle R, Peichev M, Lam G, Silverstein RL, Moore MA, Rafii S (1999) Stromal derived factor-1-induced chemokinesis of cord blood CD34(+) cells (long-term cultureinitiating cells) through endothelial cells is mediated by E-selectin. Blood 94:4011-4019

Neering SJ, Bushnell T, Sozer S, Ashton J, Rossi RM, Wang PY, Bell DR, Heinrich D, Bottaro A, Jordan CT (2007) Leukemia stem cells in a genetically defined murine model of blast-crisis CML. Blood 110:2578-2585

Neviani P, Santhanam R, Trotta R, Notari M, Blaser BW, Liu S, Mao $H$, Chang JS, Galietta A, Uttam A, Roy DC, Valtieri M, BrunerKlisovic R, Caligiuri MA, Bloomfield CD, Marcucci G, Perrotti D (2005) The tumor suppressor PP2A is functionally inactivated in blast crisis CML through the inhibitory activity of the BCR/ABLregulated SET protein. Cancer Cell 8:355-368

Neviani P, Harb JG, Oaks JJ, Santhanam R, Walker CJ, Ellis JJ, Ferenchak G, Dorrance AM, Paisie CA, Eiring AM, Ma Y, Mao HC, Zhang B, Wunderlich M, May PC, Sun C, Saddoughi SA, Bielawski J, Blum W, Klisovic RB, Solt JA, Byrd JC, Volinia S, Cortes J, Huettner CS, Koschmieder S, Holyoake TL, Devine S, Caligiuri MA, Croce CM, Garzon R, Ogretmen B, Arlinghaus RB, Chen CS, Bittman R, Hokland P, Roy DC, Milojkovic D, Apperley J, Goldman JM, Reid A, Mulloy JC, Bhatia R, Marcucci G, Perrotti D (2013) PP2A-activating drugs selectively eradicate TKI-resistant chronic myeloid leukemic stem cells. J Clin Invest 123:4144-4157

Niemann CU, Kjeldsen L, Ralfkiaer E, Jensen MK, Borregaard N (2007) Serglycin proteoglycan in hematologic malignancies: a marker of acute myeloid leukemia. Leukemia 21:2406-2410

Nowell PC, Hungerford DA (1960) Chromosome studies on normal and leukemic human leukocytes. J Natl Cancer Inst 25:85-109

Olsson B, Legros L, Guilhot F, Stromberg K, Smith J, Livesey FJ, Wilson DH, Zetterberg H, Blennow K (2014) Imatinib treatment and Abeta42 in humans. Alzheimers Dement 10:S374-S380

Passegue E, Jochum W, Schorpp-Kistner M, Mohle-Steinlein U, Wagner EF (2001) Chronic myeloid leukemia with increased granulocyte progenitors in mice lacking junB expression in the myeloid lineage. Cell 104:21-32 
Peng H, Wu Y, Duan Z, Ciborowski P, Zheng JC (2012) Proteolytic processing of SDF-1alpha by matrix metalloproteinase-2 impairs CXCR4 signaling and reduces neural progenitor cell migration. Protein Cell 3:875-882

Quaiser T, Anton R, Kuhl M (2006) Kinases and G proteins join the Wnt receptor complex. BioEssays 28:339-343

Reya T, Morrison SJ, Clarke MF, Weissman IL (2001) Stem cells, cancer, and cancer stem cells. Nature 414:105-111

Rezvani K, Price DA, Brenchley JM, Kilical Y, Gostick E, Sconocchia G, Hansmann K, Kurlander R, Douek DC, Barrett AJ (2007) Transfer of PR1-specific T-cell clones from donor to recipient by stem cell transplantation and association with GvL activity. Cytotherapy 9:245-251

Rowley JD (1973) Letter: a new consistent chromosomal abnormality in chronic myelogenous leukaemia identified by quinacrine fluorescence and Giemsa staining. Nature 243:290-293

Saudy NS, Fawzy IM, Azmy E, Goda EF, Eneen A, Abdul SEM (2014) BMl1 gene expression in myeloid leukemias and its impact on prognosis. Blood Cells Mol Dis 53:194-198

Scheller M, Schonheit J, Zimmermann K, Leser U, Rosenbauer F, Leutz A (2013) Cross talk between Wnt/beta-catenin and Irf8 in leukemia progression and drug resistance. J Exp Med 210:22392256

Sengupta A, Banerjee S (2007) Pleiotropic p27 (Kip1), BCR-ABL and leukemic stem cell: the trio in concert. Leukemia 21:25592561

Shen WF, Rozenfeld S, Kwong A, Kom ves LG, Lawrence $\mathrm{HJ}$, Largman C (1999) HOXA9 forms triple complexes with PBX2 and MEIS1 in myeloid cells. Mol Cell Biol 19:3051-3061

Si J, Collins SJ (2008) Activated Ca2 +/calmodulin-dependent protein kinase Ilgamma is a critical regulator of myeloid leukemia cell proliferation. Cancer Res 68:3733-3742

Si J, Mueller L, Collins SJ (2007) CaMKII regulates retinoic acid receptor transcriptional activity and the differentiation of myeloid leukemia cells. J Clin Invest 117:1412-1421

Siddiqui N, Borden KL (2012) mRNA export and cancer. Wiley Interdisciplinary Rev RNA 3:13-25

Slupianek A, Falinski R, Znojek P, Stoklosa T, Flis S, Doneddu V, Pytel D, Synowiec E, Blasiak J, Bellacosa A, Skorski T (2013) BCR-ABL1 kinase inhibits uracil DNA glycosylase UNG2 to enhance oxidative DNA damage and stimulate genomic instability. Leukemia 27:629-634

Sorel N, Bonnet ML, Guillier M, Guilhot F, Brizard A, Turhan AG (2004) Evidence of ABL-kinase domain mutations in highly purified primitive stem cell populations of patients with chronic myelogenous leukemia. Biochem Biophys Res Commun 323:728-730

Strathdee G, Holyoake TL, Sim A, Parker A, Oscier DG, Melo JV, Meyer S, Eden T, Dickinson AM, Mountford JC, Jorgensen HG, Soutar R, Brown R (2007) Inactivation of HOXA genes by hypermethylation in myeloid and lymphoid malignancy is frequent and associated with poor prognosis. Clin Cancer Res 13:50485055

Tauchi T, Boswell HS, Leibowitz D, Broxmeyer HE (1994) Coupling between p210bcr-abl and Shc and Grb2 adaptor proteins in hematopoietic cells permits growth factor receptor-independent link to ras activation pathway. J Exp Med 179:167-175

Timmins JM, Ozcan L, Seimon TA, Li G, Malagelada C, Backs J, Backs T, Bassel-Duby R, Olson EN, Anderson ME, Tabas I (2009) Calcium/calmodulin-dependent protein kinase II links ER stress with Fas and mitochondrial apoptosis pathways. J Clin Invest 119:2925-2941

Valk-Lingbeek ME, Bruggeman SW, van Lohuizen M (2004) Stem cells and cancer; the polycomb connection. Cell 118:409-418

Wang Y, Cai D, Brendel C, Barett C, Erben P, Manley PW, Hochhaus A, Neubauer A, Burchert A (2007) Adaptive secretion of granulocyte-macrophage colony-stimulating factor (GM-CSF) mediates imatinib and nilotinib resistance in $\mathrm{BCR} / \mathrm{ABL}+$ progenitors via JAK-2/STAT-5 pathway activation. Blood 109:2147-2155

Wang Z, Yuan H, Roth M, Stark JM, Bhatia R, Chen WY (2013) SIRT1 deacetylase promotes acquisition of genetic mutations for drug resistance in CML cells. Oncogene 32:589-598

Weissman IL (2000) Stem cells: units of development, units of regeneration, and units in evolution. Cell 100:157-168

Williams DA, Zheng Y, Cancelas JA (2008) Rho GTPases and regulation of hematopoietic stem cell localization. Methods Enzymol 439:365-393

Wodarz D (2008) Stem cell regulation and the development of blast crisis in chronic myeloid leukemia: implications for the outcome of Imatinib treatment and discontinuation. Med Hypotheses 70:128136

Yang ZF, Zhang H, Ma L, Peng C, Chen Y, Wang J, Green MR, Li S, Rosmarin AG (2013) GABP transcription factor is required for development of chronic myelogenous leukemia via its control of PRKD2. Proc Natl Acad Sci U S A 110:2312-2317

Yong AS, Keyvanfar K, Eniafe R, Savani BN, Rezvani K, Sloand EM, Goldman JM, Barrett AJ (2008) Hematopoietic stem cells and progenitors of chronic myeloid leukemia express leukemiaassociated antigens: implications for the graft-versus-leukemia effect and peptide vaccine-based immunotherapy. Leukemia 22:1721-1727

Zhang B, Ho YW, Huang Q, Maeda T, Lin A, Lee SU, Hair A, Holyoake TL, Huettner C, Bhatia R (2012) Altered microenvironmental regulation of leukemic and normal stem cells in chronic myelogenous leukemia. Cancer Cell 21:577-592

Zhao L, Moos MP, Grabner R, Pedrono F, Fan J, Kaiser B, John N, Schmidt S, Spanbroek R, Lotzer K, Huang L, Cui J, Rader DJ, Evans JF, Habenicht AJ, Funk CD (2004) The 5-lipoxygenase pathway promotes pathogenesis of hyperlipidemia-dependent aortic aneurysm. Nat Med 10:966-973

Zhao C, Chen A, Jamieson CH, Fereshteh M, Abrahamsson A, Blum J, Kwon HY, Kim J, Chute JP, Rizzieri D, Munchhof M, VanArsdale T, Beachy PA, Reya T (2009) Hedgehog signalling is essential for maintenance of cancer stem cells in myeloid leukaemia. Nature 458:776-779

Zhu J, Zhou L, Wu G, Konig H, Lin X, Li G, Qiu XL, Chen CF, Hu CM, Goldblatt E, Bhatia R, Chamberlin AR, Chen PL, Lee WH (2013) A novel small molecule RAD51 inactivator overcomes imatinibresistance in chronic myeloid leukaemia. EMBO Mol Med 5:353365 